\title{
Penggunaan Metode SBAR untuk Komunikasi Efektif antara Tenaga Kesehatan dalam Konteks Klinis
}

\author{
Laura Victoria Christina ${ }^{1 *}$, Astrid Pratidina Susilo ${ }^{2}$ \\ ${ }^{1}$ Program Studi Pendidikan Dokter, Fakultas Kedokteran, Universitas Surabaya, Surabaya-Indonesia \\ ${ }^{2}$ Laboratorium Ilmu Pendidikan Kedokteran dan Bioetik, Fakultas Kedokteran, Universitas Surabaya, \\ Surabaya-Indonesia \\ * corresponding author: lauravc158@gmail.com
}

\begin{abstract}
Interprofessional collaboration is a collaboration in health services between health professionals from diverse backgrounds. One of the most important aspects of collaborative practice in health services is the communication between health professionals. Lack of communication can cause a delay in treatment and medical errors. Ineffective communication can also represent a lack of coordination. SBAR method is an effective communication technique for health professionals. The SBAR method is useful to improve team communication in general, improve communication skills in certain situations, and also helpful during shift handover.
\end{abstract}

Keywords: interprofessional collaboration, communication, SBAR method

Abstrak-Kolaborasi interprofesional merupakan suatu kerja sama dalam pelayanan kesehatan antara profesional kesehatan yang memiliki latar belakang pendidikan berbeda. Dalam pelayanan kesehatan, salah satu hal terpenting dari praktik kolaborasi yaitu komunikasi antara tenaga kesehatan. Kurangnya komunikasi dapat menyebabkan terjadinya keterlambatan dalam melayani pasien dan kesalahan dalam menangani pasien. Komunikasi yang kurang efektif juga dapat menggambarkan koordinasi tenaga kesehatan yang kurang baik. Teknik komunikasi efektif yaitu SBAR ditetapkan sebagai standar komunikasi antara tenaga kesehatan yang berfokus terhadap pasien. Metode SBAR bermanfaat untuk meningkatkan komunikasi tim secara umum, meningkatkan keterampilan komunikasi saat situasi tertentu, dan juga berguna pada saat operan dinas.

Kata kunci: kolaborasi interprofesional, komunikasi, metode SBAR

\section{PENDAHULUAN}

Kolaborasi interprofesional merupakan suatu kerja sama dalam pelayanan kesehatan antara profesional kesehatan yang memiliki latar belakang pendidikan berbeda. Kolaborasi interprofesional mendukung pelayanan kesehatan dalam mencapai keselamatan dan kesehatan pasien. Dalam kolaborasi interprofesional, dibutuhkan kerja sama, komunikasi, dan kepastian agar perawatan yang diberikan dalam kondisi optimal. Kelompok profesional bekerja sama untuk meningkatkan kualitas pelayanan kesehatan, melakukan tindakan kolektif terhadap kebutuhan perawatan pasien, dan memberikan kualitas pelayanan yang terbaik (WHO, 2010). Hal penting dalam kolaborasi tim kesehatan yaitu proses pengambilan keputusan, rasa saling percaya dan menghargai, dan komunikasi yang efektif (Kozier et al., 2010).

Dalam pelayanan kesehatan, salah satu hal terpenting dari praktik kolaborasi yaitu komunikasi antara tenaga kesehatan. Kurangnya komunikasi dapat menyebabkan terjadinya keterlambatan dalam melayani pasien dan kesalahan dalam menangani pasien. Komunikasi yang kurang efektif juga dapat menggambarkan koordinasi tenaga kesehatan yang kurang baik. Komunikasi terkadang hanya berupa perintah dan konfirmasi saja tanpa diskusi dan transfer pengetahuan. Komunikasi yang kurang sistematis dapat menjadi hambatan untuk berinteraksi secara profesional (Mardiana, Kristina and Sulisno, 2019). Kesalahan dalam komunikasi adalah penyebab nomor satu yang dapat membahayakan pasien. The Joint Commission on Accreditation of Healthcare Organizations menyatakan bahwa kesalahan dalam komunikasi dapat menyebabkan $60 \%$ hingga $70 \%$ kematian pasien. Kesalahan dalam komunikasi muncul 
ketika informasi penting pasien ada yang keliru, hilang, dan salah tafsir (Murphy \& Dunn, 2010).

Keselamatan pasien adalah topik penting dalam standar akreditasi rumah sakit. Meningkatkan komunikasi yang efektif termasuk ke dalam sasaran keselamatan pasien. Metode komunikasi SBAR yang terdiri dari Situation, Background, Assessment, dan Recommendation merupakan kerangka komunikasi efektif dan ditetapkan sebagai standar komunikasi antara tenaga kesehatan yang berfokus terhadap pasien (SNARS, 2018). Dalam bidang pelayanan, contohnya, metode SBAR membantu perawat untuk menyusun cara berpikir, mengolah informasi, menyampaikan pesan, dan mempermudah berdiskusi dengan dokter (Mardiana, Kristina, \& Sulisno, 2019).

Literatur tentang SBAR banyak melaporkan penelitian yang menguji efektifitas dan hasil dari pelaksanaan metode SBAR (Müller et al., 2018). Literatur yang membahas tentang cara penggunaan SBAR masih terbatas. Metode SBAR masih belum sepenuhnya terlaksanakan. Pengetahuan tentang SBAR juga masih terbatas (Ita, Suradika, \& Kurniati, 2016). Oleh karena itu, penulisan ini bertujuan untuk menjelaskan tentang komunikasi SBAR beserta contoh penggunaannya, manfaat metode SBAR, dan faktor yang memengaruhi komunikasi SBAR.

\section{Komunikasi SBAR}

Metode SBAR terdiri dari situation, background, assessment, recommendation. Situation menggambarkan keadaan situasi yang terjadi seperti yang dialami pasien saat ini, keluhan utama pasien, dan mengapa perawat menghubungi dokter. Background membahas tentang apa yang melatarbelakangi kondisi pasien, tanda-tanda vital dan riwayat penyakit, kondisi yang akan datang, dan keadaan yang mengarah pada kondisi tersebut. Assessment merupakan hasil pengkajian pasien dan kemungkinan masalah yang akan dihadapi pasien. Recommendation yaitu mengusulkan tindakan yang harus dilakukan terkait kondisi pasien saat ini (Pope, Rodzen, \& Spross, 2008).

Berikut adalah dua contoh diskusi sebagai ilustrasi penggunaan SBAR dalam konteks klinis. Yang pertama antara mahasiswa kedokteran dan dokter pembimbing klinis, yang kedua antara perawat dan dokter. Pada masing-masing contoh, kami menyajikan perbandingan diskusi dengan dan tanpa penggunaan metode SBAR.

Berikut ini ilustrasi pertama, diskusi antara mahasiswa dan dokter pembimbing klinis.

\begin{tabular}{|c|c|c|}
\hline \multicolumn{3}{|c|}{ Tanpa menggunakan metode SBAR } \\
\hline Mahasiswa & : & $\begin{array}{l}\text { "Selamat pagi Dr. Adi. Saya Kevin, saya seorang dokter muda di } \\
\text { Rumah Sakit Sehat Sentosa." }\end{array}$ \\
\hline $\begin{array}{l}\text { Dokter } \\
\text { pembimbing }\end{array}$ & : & “Selamat pagi dek Kevin. Ada perlu apa ya, Dik ?" \\
\hline Mahasiswa & : & $\begin{array}{l}\text { "Saya ingin melaporkan pasien bernama Tn. Yanto, yang berusia } 23 \\
\text { tahun, yang berada di IGD." }\end{array}$ \\
\hline $\begin{array}{l}\text { Dokter } \\
\text { pembimbing }\end{array}$ & : & “Apa keluhan pasien tersebut?" \\
\hline Mahasiswa & : & $\begin{array}{l}\text { "Pasien mengeluh sesak napas dan disertai bunyi napas. Pasien } \\
\text { merasa dada sesak dan juga batuk berdahak." }\end{array}$ \\
\hline $\begin{array}{l}\text { Dokter } \\
\text { pembimbing }\end{array}$ & : & “Tanda-tanda vitalnya bagaimana?” \\
\hline Mahasiswa & : & “TD 130/87 mmHg, nadi 97 x/menit, dan RR 25 x/menit." \\
\hline $\begin{array}{l}\text { Dokter } \\
\text { pembimbing }\end{array}$ & : & "Apakah ada riwayat penyakit sebelumnya?" \\
\hline Mahasiswa & : & $\begin{array}{l}\text { "Pada usia } 20 \text { tahu pasien mengatakan pernah mengalami gejala } \\
\text { seperti ini. Pasien juga mengaku merokok sejak usia } 18 \text { tahun." }\end{array}$ \\
\hline
\end{tabular}




\begin{tabular}{|c|c|c|}
\hline $\begin{array}{l}\text { Dokter } \\
\text { pembimbing }\end{array}$ & : & "Menurut kamu, apa diagnosis dan terapinya?" \\
\hline Mahasiswa & $:$ & $\begin{array}{l}\text { "Sepertinya Tn. Yanto mengalami gejala yang berhubungan dengan } \\
\text { asma. Terapi yang diberikan yaitu inhalasi salbutamol." }\end{array}$ \\
\hline $\begin{array}{l}\text { Dokter } \\
\text { pembimbing }\end{array}$ & : & $\begin{array}{l}\text { "Baik, saya akan memeriksa Tn. Yanto dan mendiskusikannya lebih } \\
\text { lanjut denganmu." }\end{array}$ \\
\hline \multicolumn{3}{|c|}{ Dengan menggunakan metode SBAR } \\
\hline \multirow[t]{3}{*}{ Mahasiswa } & . & $\begin{array}{l}\text { Situation: "Selamat pagi Dr. Adi. Saya Kevin, saya seorang dokter } \\
\text { muda di Rumah Sakit Sehat Sentosa. Saya ingin melaporkan pasien } \\
\text { bernama Tn. Yanto yang berada di IGD. Pasien datang dengan } \\
\text { keluhan sesak napas dan disertai bunyi napas. Pasien merasa dada } \\
\text { sesak dan juga batuk berdahak. } \\
\text { Background: "Pasien merupakan seorang pria berusia } 23 \text { tahun. TD } \\
130 / 87 \mathrm{mmHg} \text {, nadi } 97 \mathrm{x} / \text { menit, dan RR } 25 \mathrm{x} / \text { menit. Pada usia } 20 \\
\text { tahu pasien mengatakan pernah mengalami gejala seperti ini. } \\
\text { Pasien mengaku merokok sejak usia } 18 \text { tahun. }\end{array}$ \\
\hline & & $\begin{array}{l}\text { Assessment: "Sepertinya Tn. Yanto mengalami gejala yang } \\
\text { berhubungan dengan asma." }\end{array}$ \\
\hline & & $\begin{array}{l}\text { Recommendation: "Menurut saya, Tn. Yanto dapat diberi terapi } \\
\text { inhalasi salbutamol." }\end{array}$ \\
\hline $\begin{array}{l}\text { Dokter } \\
\text { pembimbing }\end{array}$ & : & $\begin{array}{l}\text { "Selamat pagi dek Kevin. Baik, saya akan memeriksa Tn. Yanto dan } \\
\text { mendiskusikannya lebih lanjut denganmu." }\end{array}$ \\
\hline
\end{tabular}

Dengan menggunakan SBAR, komunikasi menjadi lebih efektif dan ringkas. Dokter pembimbing dapat mengurangi jumlah pertanyaan yang diajukan karena mahasiswa telah melaporkan dengan lengkap dan terstruktur. Kata 'situation', 'background', 'assessment', dan 'recommendation' dituliskan dalam ilustrasi di atas sebagai contoh dan tidak harus diucapkan pada diskusi nyata.

Berikut ini ilustrasi pertama, diskusi antara perawat dan dokter.

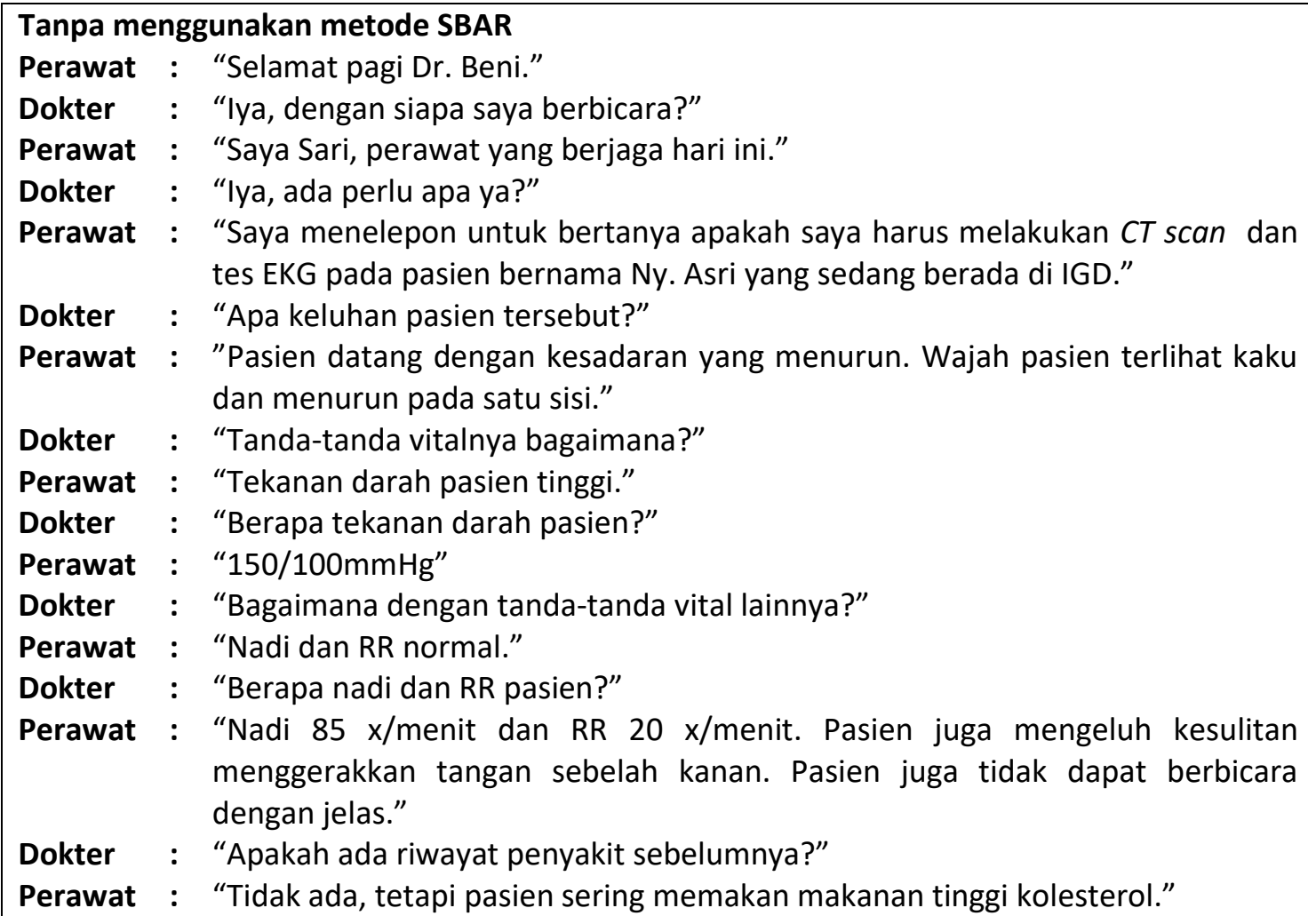
menggerakkan tangan sebelah kanan. Pasien juga tidak dapat berbicara dengan jelas."

Dokter : "Apakah ada riwayat penyakit sebelumnya?"

Perawat : "Tidak ada, tetapi pasien sering memakan makanan tinggi kolesterol." 
Dokter : "Saya akan ke sana lima menit lagi. Selagi itu, tolong lakukan CT scan dan tes EKG ya."

\section{Dengan menggunakan metode SBAR}

Perawat : Situation: "Selamat pagi Dr. Beni. Saya Sari, perawat yang berjaga hari ini. Saya menelepon untuk berbicara tentang pasien bernama Ny. Asri di IGD. Pasien datang dengan kesadaran yang menurun. Wajah pasien terlihat kaku dan menurun pada satu sisi. Pasien kesulitan menggerakkan tangan sebelah kanan. Pasien juga tidak dapat berbicara dengan jelas.

Background: "Ny. Asri adalah seorang wanita berusia 55 tahun. TD 150/100 $\mathrm{mmHg}$, nadi $85 \mathrm{x} /$ menit, dan RR $20 \mathrm{x} /$ menit. Pasien sering memakan makanan tinggi kolesterol.

Assessment: "Sepertinya Ny. Asri mengalami gejala yang berhubungan dengan stroke."

Recommendation: "Apakah Dr. Beni bisa menemui pasien? Apakah saya harus melakukan CT scan dan tes EKG?"

Dokter : "Saya akan ke sana lima menit lagi. Selagi itu, tolong lakukan CT scan dan tes EKG ya."

\section{Manfaat Metode SBAR}

Metode komunikasi SBAR memungkinkan informasi penting ditransfer secara akurat (Achrekar et al., 2016). Praktik kolaborasi interprofesional dan pelaksanaan komunikasi SBAR menjadi strategi untuk meningkatkan kolaborasi interprofesi dalam pelayanan kesehatan di rumah sakit. Kajian sistematik yang dilakukan oleh Müller et al. (2018) menjelaskan dampak pada pasien dari diterapkannya komunikasi SBAR. Dampak tersebut dapat berupa keselamatan, kepuasan, dan status fungsional pasien. Sebanyak 26 pasien diamati. Hasilnya, dampak tersebut meningkat secara drastis pada 8 pasien, pada 11 pasien meningkat tetapi tidak signifikan, tidak ada perubahan pada 6 pasien, dan sisanya mengalami kejadian yang tidak diharapkan tetapi tidak terdapat penurunan yang signifikan pada keselamatan pasien. Dua penelitian (18.2\%) menyebutkan bahwa manfaat metode SBAR untuk meningkatkan komunikasi tim secara umum. Selain itu, Lima penelitian (45.5\%) berpendapat metode SBAR untuk mengembangkan kemampuan antara perawat atau interprofesional pada operan pasien. Lalu empat penelitian lainnya (36.4\%) mengatakan metode SBAR bertujuan untuk meningkatkan keterampilan komunikasi saat situasi tertentu seperti berbicara melalui telepon (Müller et al., 2018).

Achrekar et al. (2016) melakukan penelitian yang melibatkan 17 perawat. Sebesar $79 \%$ perawat berpendapat bahwa metode SBAR berguna pada saat operan dinas. Lalu $63 \%$ perawat juga mengatakan bahwa informasi metode SBAR dapat meningkatkan keselamatan pasien. Selain itu $53 \%$ perawat merasa perlu adanya keterlibatan pasien berkaitan dengan metode SBAR. Keterlibatan pasien sangat penting karena memberikan kesempatan untuk perawat mengajukan pertanyaan, mengklarifikasi, dan saling memberikan informasi. Hal ini dapat mengurangi kecemasan perawat, membuat mereka lebih puas dengan rencana perawatan, dan mengetahui hal-hal apa yang harus diperhatikan (Achrekar et al., 2016).

Di Indonesia, penelitian yang dilakukan oleh Astuti, Ilmi, dan Wati (2019) menyebutkan bahwa komunikasi SBAR bermanfaat bagi perawat dan pasien serta dalam hal keselamatan pasien. Manfaat bagi perawat yaitu meningkatkan kualitas operan pasien, mengetahui tentang kondisi pasien dengan mudah, dan meningkatkan komunikasi yang efektif. Bagi pasien, SBAR bermanfaat karena pasien merasa senang sebab kondisi pasien dapat tercatat lebih detail. Manfaat SBAR untuk keselamatan pasien yaitu memudahkan pemantauan pasien, meningkatkan kualitas perawatan pasien, dan mengurangi risiko kejadian tidak diharapkan(Astuti, Ilmi, \& Wati, 2019). 
Mardiana et al. (2019) melakukan penelitian di ruang rawat inap RS PKU Muhammadiyah Mayong sebagai kelompok intervensi dan RS Aisyiyah Kudus sebagai kelompok kontrol. Hasil penelitian menunjukkan bahwa setelah mendapatkan pelatihan komunikasi SBAR, terdapat perbedaan yang signifikan antara kelompok intervensi dengan kelompok kontrol dalam keterampilan komunikasi perawat dan dokter (Mardiana, Kristina, \& Sulisno, 2019).

\section{Faktor yang memengaruhi komunikasi SBAR}

Beberapa faktor yang memengaruhi komunikasi SBAR yaitu sikap, motivasi, kepuasan kerja, dan pengetahuan (Cahyono, 2008). Rut et al. (2018) melakukan penelitian di rumah sakit swasta bagian Indonesia Barat. Hasil penelitian tersebut menunjukkan bahwa terdapat hubungan antara komunikasi SBAR dengan sikap perawat ketika menyerahkan pasien ke perawat UGD (Rut et al., 2018). Berdasarkan hasil penelitian Bawelle et al. (2013), sikap berkaitan erat dengan perilaku perawat dalam upaya pelaksanaan keselamatan pasien. Jika semakin baik sikap perawat, maka perilaku perawat semakin baik dalam upaya pelaksanaan keselamatan pasien. Peneliti berasumsi bahwa sikap kerja perawat juga berhubungan dengan pelaksanaan komunikasi SBAR ketika operan dinas. Perawat yang menunjukkan respon sikap yang positif cenderung akan melakukan semua aspek komunikasi SBAR pada saat operan dinas. Aspek komunikasi SBAR yang diterapkan dapat berupa memberikan rekomendasi tindakan dan pengecekan ulang informasi oleh perawat pada dinas berikutnya (Rezkiki \& Utami, 2017).

Perawat juga harus memiliki motivasi untuk melakukan sesuatu. Motivasi merupakan faktor penting yang mendorong seseorang untuk memberikan kinerja terbaik dalam mencapai tujuan. Ketika tidak ada motivasi, maka hasil dari sesuatu yang dilakukan tidak maksimal. Begitu juga saat melakukan komunikasi SBAR, harus ada motivasi (Fadlia, 2020). Nur Fitria (2013) melakukan penelitian tentang efektivitas pelatihan komunikasi SBAR dalam meningkatkan motivasi dan psikomotor perawat di ruang medikal bedah RS PKU Muhammadiyah Surakarta. Sesudah pelatihan komunikasi SBAR, terjadi peningkatan nilai ratarata motivasi perawat yaitu dari 84,45 menjadi 86,40 (Fitria, 2017).

Kepuasan kerja juga memengaruhi komunikasi SBAR. Kepuasan kerja merupakan keadaan emosional yang menyenangkan setelah membandingkan kinerja dengan harapannya. Perawat akan merasa sangat puas bila kinerja sesuai atau melebihi harapan. Hal tersebut dapat memengaruhi perawat dalam menerapkan metode komunikasi SBAR (Fadlia, 2020).

Penting juga bagi perawat untuk memiliki pengetahuan tentang komunikasi yang efektif. Perawat yang memiliki pengalaman yang cukup dapat meningkatkan pengetahuan tentang teknik komunikasi SBAR (Watulangkow et al., 2020). Penelitian yang dilakukan oleh Susanti et al. (2014) menyatakan bahwa perawat mengetahui dan memahami tentang komunikasi SBAR seperti konsep dasar, pengertian, tujuan, dan manfaat. Namun, perawat belum sepenuhnya melaksanakan komunikasi SBAR. Ini terjadi karena faktor budaya dan kebiasaan kerja perawat. Pada saat operan dinas perawat sering terlalu berfokus pada hal-hal inti yaitu penyampaian kondisi atau situasi pasien, diagnosa keperawatan, dan latar belakang. Hal lain dianggap tidak terlalu penting seperti rekomendasi tindakan, merangkum informasi untuk perawat dinas berikutnya, memperkenalkan diri, dan memberi salam (Rezkiki \& Utami, 2017).

\section{SIMPULAN}

Metode komunikasi SBAR yang terdiri dari Situation, Background, Assessment, dan Recommendation membantu tenaga kesehatan untuk berkomunikasi secara efektif. Manfaat metode SBAR yaitu untuk meningkatkan komunikasi tim secara umum, mengembangkan kemampuan antara perawat atau interprofesional pada operan pasien, dan meningkatkan keterampilan komunikasi saat situasi tertentu. Beberapa faktor yang dapat memengaruhi komunikasi SBAR yaitu sikap, motivasi, kepuasan kerja, dan pengetahuan. 


\section{SARAN}

Setelah mengetahui pentingnya SBAR, diharapkan metode SBAR dapat diperkenalkan kepada mahasiswa profesi kesehatan sejak masih menjalankan pendidikan. Dengan begitu, mahasiswa akan memiliki pengetahuan yang dalam tentang metode SBAR. Mahasiswa juga akan terbiasa menggunakan metode ini sehingga dapat berkomunikasi secara lebih efektif saat bekerja dengan sesama tenaga kesehatan dalam praktik layanan kesehatan.

\section{PUSTAKA ACUAN}

Achrekar, M. S. et al. (2016) 'Introduction of situation, background, assessment, recommendation into nursing practice: A prospective study', Asia-Pacific Journal of Oncology Nursing, 3(1), 45-50. https://doi.org/10.4103/2347-5625.178171

Astuti, N., Ilmi, B. and Wati, R. (2019) 'Penerapan komunikasi situation, background, assesment, recomendation (SBAR) pada perawat dalam melaksanakan handover', Indonesian Journal of Nursing Practices, 3(1), 42-51. https://doi.org/10.18196/ijnp.3192

Cahyono, J. B. S. B. (2008) Membangun Budaya Keselamatan Pasien dalam Praktek Kedokteran, Kanisius, Yogyakarta.

Fadlia, N. (2020). Hubungan Penerapan Komunikasi SBAR saat Handover dengan Kepuasan Kerja Perawat di Ruang Rawat Inap RSUD Labuang Baji Makassar, Skripsi, Sekolah Tinggi Ilmu Kesehatan Panakkukang Makassar, Makassar, viewed 10 May 2021, https://stikespanakkukang.ac.id/assets/uploads/alumni/7fb3bf0c0b746c3857f160a87 d77c88c.pdf

Fitria, C. N. (2017) 'Efektifitas pelatihan komunikasi SBAR dalam meningkatkan motivasi dan psikomotor perawat di ruang medikal bedah RS PKU Muhammadiyah Surakarta', Prosiding Seminar Nasional \& Internasional, 109-111. https://jurnal.unimus.ac.id/index.php/psn12012010/article/view/860

Ita, Suradika, A. and Kurniati, T. (2016) Hubungan Motivasi dan Pengetahuan Perawat dengan Komunikasi Efektif saat Timbang Terima Pasien di IRNA A RS Kepresidenan RSPAD Gatot Soebroto, Tesis, Universitas Muhammadiyah Jakarta, Jakarta, viewed 20 July 2021, http://perpus.fikumj.ac.id/index.php?p=fstream-pdf\&fid=2368\&bid=3436

Kozier et al. (2010) Buku Ajar Fundamental Keperawatan: Konsep, Proses, dan Praktik, 7th edn, EGC, Jakarta.

Mardiana, S. S., Kristina, T. N. and Sulisno, M. (2019) 'Penerapan komunikasi SBAR untuk meningkatkan kemampuan perawat dalam berkomunikasi dengan dokter', Jurnal IImu Keperawatan dan Kebidanan, 10(2), 273. http://dx.doi.org/10.26751/jikk.v10i2.48

Müller, M. et al. (2018) 'Impact of the communication and patient hand-off tool SBAR on patient safety: A systematic review', BMJ Open, 8(8). https://doi.org/10.1136/bmjopen-2018-022202

Murphy, J. G. and Dunn, W. F. (2010) 'Medical errors and poor communication', Chest, 138(6), 1292-1293. https://doi.org/10.1378/chest.10-2263

Pope, B. B., Rodzen, L. and Spross, G. (2008) 'Raising the SBAR: How better communication improves patient outcomes', Nursing, 38(3), 41-43. https://doi.org/10.1097/01.NURSE.0000312625.74434.e8

Rezkiki, F. and Utami, G. S. (2017) 'Faktor yang berhubungan dengan penerapan komunikasi SBAR di ruang rawat inap', Jurnal Human Care, 1(2), 9-21. http://dx.doi.org/10.32883/hcj.v1i2.35

Rut, A. et al. (2018) 'The correlation between attitude and motivation with the implementation of SBAR communication technique done by emergency room nurses while doing patient handover in private hospital in west region of Indonesia', Jurnal Keperawatan, 6(2), 38-46. https://ojs.uph.edu/index.php/NCJK/article/view/1907/735 
SNARS (2018) SBAR - Komunikasi Efektif di Rumah Sakit, viewed 9 July 2021, https://snars.web.id/rs/sbar-komunikasi-efektif-di-rumah-sakit.

Watulangkow, M. et al. (2020) 'Pengetahuan perawat terhadap teknik komunikasi SBAR di satu rumah sakit di Indonesia Barat', Jurnal Keperawatan Raflesia, 2(2), 81-88. https://doi.org/10.33088/jkr.v2i2.558

WHO (2010) Framework for Action on Interprofessional Education \& Collaborative Practice, viewed 29 May 2021, https://apps.who.int/iris/handle/10665/70185 